\title{
Stimulatory Effect of the Magnetic Treatment Prior to Sowing on the Germination and Initial Growth of Triticale Seeds
}

\author{
M.Florez, M.V. Carbonell, E.Martinez, J.Alvarez \\ Department of Agroforestry Engineering-Physics Section, School of Agricultural, Food and Biosystems Engineering. Ciudad \\ Universitaria s/n 28040 Madrid, Spain
}

\begin{abstract}
The The objective of this paper is to evaluate the effects on germination of triticale ( $X$ Triticosecale Wittmack) seeds exposed to one of two magnetic field strengths ( 125 or $250 \mathrm{mT}$ ) for different periods of time.

When the seeds were exposed to magnetic fields, the maximum percentage of germinated seeds was significantly increased, occasionally until 19\% compared to control. The time required to the onset of the germination in magnetically treated seeds was reduced regarding control. As well as the mean germination time (MGT) of triticale seeds was significantly reduced The times required to germinate $1,10,25,50,75$ and 90 percent of seeds were also reduced
\end{abstract}

Keywords-Germination, magnetic treatment, , presowing treatment, $X$ Triticosecale Wittmack.

\section{INTRODUCTION}

The effects on living systems of exposure to a magnetic field, particularly on germination of seeds and growth of plants, have been the object of numerous researches.. In general, the enhancement of growth due to magnetic field exposure appears to have been confirmed by many scientists. Some have tried to determine effects related with seed germination, such as changes in biochemical activity, curvature, magnetotropism and germination rate. Yano et al. (2001) observed induction of primary root curvature in radish seedlings in a static magnetic field; the roots responded tropically to magnetic field, with the tropism appearing to be negative. These roots responded significantly to the south pole of the magnet. Cakmak et al (2010) observed that the application of magnetic field doses of $4 \mathrm{mT}$ and $7 \mathrm{mT}$ promoted germination ratios of bean and wheat seeds. Carbonell et al. (2011) reported that treated pea plants grew higher and heavier than control; the greatest differences were observed for seeds treated with doses of $125 \mathrm{mT}$ and $250 \mathrm{mT}$, for $24 \mathrm{~h}$ or permanent. Florez et al (2007) observed an stimulation on the growth of maize seeds exposed to 125 and $250 \mathrm{mT}$ stationary magnetic field. Shine et al (2011) found that exposure to magnetic fields improved parameters like water uptake, leaf photosynthetic efficiency and leaf protein content.

Although the mechanisms at work in plants and other living systems exposed to a magnetic field are still not well known, several theories have been proposed, including biochemical changes or altered enzyme activities (Phirke et al, 1996). Garcia and Arza (2001) carried out an experimental study on water absorption by lettuce seeds previously exposed to a stationary magnetic field of $1-10 \mathrm{mT}$. They reported an increase in water uptake due to the applied magnetic field, which could explain of the increase in the germination speed of treated lettuce seeds.

The main objective of this study is to determine the effects of magnetic treatment (in addition to the geomagnetic field) on the germination and initial growth of triticale seeds. This objective, early growth of triticale, has a practical application in agriculture science.

\section{MATERIAL AND METHODS}

Germination and growth tests of triticale were carried out under laboratory conditions with natural light and the minimum and maximum temperature of $18{ }^{\circ} \mathrm{C}$ and $22{ }^{\circ} \mathrm{C}$ in winter, according to guidelines issued by the International Seed Testing Association (ISTA, 2004) with only slight modifications.

\subsection{Seeds}

Triticale (X Triticosecale Wittmack) is a wheat and rye hybrid. Although triticale of grain size, shape and colour resembles that wheat more than rye, still triticale grain is usually larger and longer than wheat grain. Adapted to a wide range of soils and requiring only moderate fertility and moisture, it does not tolerate flooding and is only slightly drought resistant. Seeds were supplied by the Spanish Office of Vegetable Varieties, which guarantees high seed viability and homogeneity and thus significant results with smaller samples.

\subsection{Magnetic treatment}


Magnetic treatment consisted of different doses (Pi) due to variation in exposure time (t) and the magnetic field induction (B). The static magnetic field was generated by permanent ring magnets, with strengths of $125 \mathrm{mT}$ or 250 $\mathrm{mT}$, external diameter of $7.5 \mathrm{~cm}$, internal diameter of 3 $\mathrm{cm}$, and height of $1 \mathrm{~cm}$ for $125 \mathrm{mT}$ magnets and $1.5 \mathrm{~cm}$ for $250 \mathrm{mT}$ magnets. Ring analogous to the ring magnets, of the same material but without magnetic induction, were used as blind (Control). Magnetic doses were obtained by exposing the seeds to each magnetic field for different times as shown in Table 1. The experimental design involves four replicates $(n=4)$ with 25 seeds. Thus, groups of 100 seeds were subjected to each magnetic treatment, and an analogous group was used as control. Each replicate was placed in the hollow of a magnet, before coming into contact with water, prior to sowing.

Table.1:Coding of magnetic treatments and exposure time.

\begin{tabular}{ccc}
\hline Time & $\mathbf{1 2 5} \mathbf{~ m T}$ & $\mathbf{2 5 0} \mathbf{~ m T}$ \\
0 & $\mathrm{C}$ & $\mathrm{C}$ \\
$1 \mathrm{~min}$ & $\mathrm{P} 1$ & $\mathrm{P} 6$ \\
$10 \mathrm{~min}$ & $\mathrm{P} 2$ & $\mathrm{P} 7$ \\
$20 \mathrm{~min}$ & $\mathrm{P} 3$ & $\mathrm{P} 8$ \\
$1 \mathrm{~h}$ & $\mathrm{P} 4$ & $\mathrm{P} 9$ \\
$24 \mathrm{~h}$ & $\mathrm{P} 5$ & $\mathrm{P} 10$ \\
\hline
\end{tabular}

\subsection{Germination test}

The goal of this test was to determine the possible influence of magnetic treatment on the time required for germination. Germination was tested by placing 25 treated seeds per Petri dish around a circular line, on filter papers soaked with $12 \mathrm{ml}$ of distilled water. These Petri dishes were placed on top of a blind-ring, lacking magnetic induction. Petri dishes with seeds were labeled and randomly located.

Experimental groups P1-P5 (125 mT) and P6-P10 (250 $\mathrm{mT}$ ), and control $\mathrm{C}$ ran simultaneously. For each treatment the number of germinated seeds was counted every two hours, to determine the time necessary to achieve the final maximum percentage of germinated seeds $\left(G_{\max }\right)$. Seeds were considered germinated when their radicle measured at least $1 \mathrm{~mm}$.

The rate of germination was assessed by determining the mean germination time (MGT) and time required to germinate $1,10,25,50,75$ and 90 percent of seeds (parameters $\mathrm{T}_{1}, \mathrm{~T}_{10}, \mathrm{~T}_{25}, \mathrm{~T}_{50}, \mathrm{~T}_{75}$ and $\mathrm{T}_{90}$ ).

\subsection{Growth test}

The objective of this test was to evaluate length and weight of triticale plants subjected to magnetic doses described as above during the first stages of development $\left(2^{\text {nd }}, 4^{\text {th }}\right.$ and $6^{\text {th }}$ days after seeding). Control $\mathrm{C}$ ran simultaneously while treated seeds were exposed to doses P1-P10. The treated seeds with their long axes vertical were glued to filter paper with a non toxic adhesive. Each filter paper with seeds was rolled and placed in a vessel containing distilled water. Rolls carrying 25 seeds were used for each magnetic dose and for control (non-exposed seeds). All vessels containing rolls with seeds were numerically labelled and placed randomly during the test. No other substance was added to the water during the experimental period. Growth was measured as follows: total length (stem + root) and stem length in $\mathrm{mm}$; total fresh weight (stem + root) and fresh stem weight in mg. At 2 and 4 days after seeding, the rolls of filter paper were unrolled and the length of seedlings was measured; the filter papers were then re-rolled and placed again in the vessels in order to evaluate, on the $6^{\text {th }}$ day their length and fresh plant weight of the same group of seedlings.

\subsection{Statistical analysis}

Germination test. Statistical analysis of variance and mean comparisons $\quad(\mathrm{p} \leq 0.001 ; \quad 0.001 \leq \mathrm{p} \leq 0.01$; $0.01 \leq \mathrm{p} \leq 0.05$ ) was performed using the Seedcalculator software developed for seed germination data analysis by Plant Research International; the software provides the germination curves for each treatment, a comparison of the results of all the treatments and a comparison of those results with the result of the control.

Growth test. Data statistics were analysed with SPSS 11.0 for Windows software (v.18). Results were subjected to an analysis of variance (ANOVA) to detect differences between the mean of parameters. Normality of data and homogeneity of variance, were checked with the Kolmogorov-Smirnov and Levene tests, respectively. Means were compared using Tukey test (multiple comparisons) and Dunnet test to detect differences between the parameters of treated plants and control.

\section{RESULTS AND DISCUSSION}

\subsection{Germination test}

The percentage of germinated seeds $\left(\mathrm{G}_{\max }\right)$ and the time required for germination (parameters MGT, $T_{1}-T_{90}$ ) were determined for each dose, expressed as the mean of the four replicates and their standard error; the germination parameters obtained from triticale seeds exposed to 125 mT magnetic field (doses P1-P5), and the results obtained for doses of P6-P10 (250 mT) are provided in Table 2 and Table 3 respectively.

The number of germinated seeds $\left(\mathrm{G}_{\max }\right)$, from 80 to $99 \%$, corroborates the high quality of seeds. Fewer than $90 \%$ of seeds exposed to a magnetic field for less than 20 minutes germinated earlier than the control seeds; parameters $T_{10}$ $-\mathrm{T}_{90}$ and the mean germination time were reduced for all the applied magnetic doses. 
While the mean germination time (MGT) of control seeds was $19.20 \pm 0.24 \mathrm{~h}$, this parameter was significantly reduced for doses P3 $(18.48 \pm 0.24 \mathrm{~h}), \mathrm{P} 4(18.24 \pm 0.24 \mathrm{~h})$, P5 (18.00 $\pm 0.24 \mathrm{~h}), \mathrm{P} 8$ (18.48 $\pm 0.24 \mathrm{~h}), \mathrm{P} 9(18.24 \pm 0.24 \mathrm{~h})$

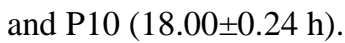

The time required to germinate $1 \%$, parameter $\mathrm{T}_{1}$, of seeds exposed to a magnetic field was less than control. As $T_{1}$ is closely related to the onset of germination, these results indicate that triticale seeds exposed to a magnetic field sprouted earlier.

The time required for germination recorded for each treatment was, in general, less than the corresponding control values; thus the rate of germination of treated seeds was higher than that of the untreated seeds (C).

\subsection{Growth test}

Fig. 1 shows the mean total length of triticale seedlings measured on the $2^{\text {nd }}$ day after seeding for all doses, compared with control. On the $2^{\text {nd }}$ day, greatest differences in mean total length were observed in doses P10 (11.14 $\pm 0.41 \mathrm{~mm})$ and P5 $(10.52 \pm 0.45 \mathrm{~mm})$, compared with control $(6.5 \pm 0.44 \mathrm{~mm})$.

Results of mean total length measured on the $4^{\text {th }}$ day are shown in Fig. 2. While the mean total length of control was $40.00 \pm 2.22 \mathrm{~mm}$, the greatest length of seedlings was obtained for doses P10 $(70.97 \pm 1.92 \mathrm{~mm})$ and P9 $(69.98 \pm 1.91 \mathrm{~mm})$.
Fig. 3 shows results measured on the $6^{\text {th }}$ day after seeding; plants with all doses were higher than control plants; the greatest increases were obtained for P10 $(138.28 \pm 2.40 \mathrm{~mm})$ and $\mathrm{P} 8(125.96 \pm 4.64 \mathrm{~mm})$ compared with control $(82.26 \pm 4.43 \mathrm{~mm})$. Consequently, all plants exposed to magnetic fields prior sowing grew higher than control.

Although the mechanisms at work in plants and other living systems exposed to a magnetic field are still not well known, several theories have been proposed, including biochemical changes or altered enzyme activities (Phirke et al, 1996). Garcia and Arza (2001) carried out an experimental study on water absorption by lettuce seeds previously exposed to a stationary magnetic field of $1-10 \mathrm{mT}$. They reported an increase in water uptake due to the applied magnetic field, which could explain of the increase in the germination speed of treated lettuce seeds.

Our results are in agreement with the germination data of maize seeds obtained by Aladjadjiyan (2002), who found an increase in germination and shoot development in seeds exposed to $150 \mathrm{mT}$ magnetic field for $10,15,20$ and 30 minutes. Podlesni, Pietruszewski and Podlesna (2004) found magnetic treatment of $30 \mathrm{mT}$ and $85 \mathrm{mT}$ on two broad bean cultivars affected positively the germination and emergence.

Table.2: Germination parameters determined for triticale seeds exposed to $125 \mathrm{mT}$ stationary magnetic fields, expressed as mean value and standard error and as percentage.

$G_{m a x}:$ number of germinated seeds (\%); MGT: Mean germination time; $T_{1}, T_{10}, T_{25}, T_{50}, T_{75}, T_{90}$ : time needed to obtain 1, 10 , $25,50,75$ and $90 \%$ of seeds to germinate, expressed in hours. Letters indicate differences vs. control: $c(p<0.001) ; b$ $(0.001<p<0.01) ; a(0.01<p<0.05)$. Doses $125 \mathrm{mT}$ : P1 (1 min), P2 (10 min), P3 (20 min), P4 (1hour), P5 (24 hours); C

(Control).

\begin{tabular}{|c|c|c|c|c|c|c|c|c|c|c|c|c|c|c|c|}
\hline & $\mathbf{G}_{\mathbf{m}}$ & & & & & & & & & & & $\mathbf{T}_{9}$ & & & \\
\hline $\begin{array}{l}\mathbf{5} \\
\mathbf{m} \\
\mathbf{T}\end{array}$ & $\%$ & $\begin{array}{c}\text { hour } \\
\mathbf{s}\end{array}$ & $\%$ & $\begin{array}{c}\text { hour } \\
\mathbf{s}\end{array}$ & $\%$ & $\begin{array}{c}\text { hour } \\
\mathbf{s}\end{array}$ & $\%$ & $\begin{array}{c}\text { hour } \\
\text { s }\end{array}$ & $\%$ & $\begin{array}{c}\text { hour } \\
\mathbf{s}\end{array}$ & $\%$ & $\begin{array}{c}\text { hour } \\
\mathbf{s}\end{array}$ & $\%$ & $\begin{array}{c}\text { hour } \\
\mathbf{s}\end{array}$ & $\%$ \\
\hline $\mathbf{C}$ & $\begin{array}{c}80 \pm \\
1.6 \\
3\end{array}$ & $\begin{array}{c}15.12 \\
\pm \\
0.24\end{array}$ & 100 & $\begin{array}{c}16.80 \\
\pm \\
0.24\end{array}$ & 100 & $\begin{array}{c}18.00 \\
\pm \\
0.24\end{array}$ & 100 & $\begin{array}{c}19.20 \\
\pm \\
0.24\end{array}$ & 100 & $\begin{array}{c}20.40 \\
\pm \\
0.24\end{array}$ & 100 & - & - & $\begin{array}{c}19.20 \\
\pm \\
0.24\end{array}$ & 100 \\
\hline $\mathbf{P}_{1}$ & $\begin{array}{c}81 \pm \\
4.7 \\
3\end{array}$ & $\begin{array}{c}14.88 \\
\pm \\
0.48\end{array}$ & $\begin{array}{c}98.41 \\
\pm \\
3.17\end{array}$ & $\begin{array}{c}16.56 \\
\pm \\
0.24\end{array}$ & $\begin{array}{c}98.57 \\
\pm \\
2.86\end{array}$ & $\begin{array}{c}17.76 \\
\pm \\
0.24\end{array}$ & $\begin{array}{c}98.67 \\
\pm \\
1.33\end{array}$ & $\begin{array}{c}19.20 \\
\pm \\
0.24\end{array}$ & $\begin{array}{c}100.0 \\
0 \pm \\
1.25\end{array}$ & $\begin{array}{c}20.40 \\
\pm \\
0.24\end{array}$ & $\begin{array}{c}100.0 \\
0 \pm \\
1.18\end{array}$ & - & - & $\begin{array}{c}19.20 \\
\pm \\
0.24\end{array}$ & $\begin{array}{c}100.0 \\
0 \pm \\
1.25\end{array}$ \\
\hline $\mathbf{P}_{2}$ & $\begin{array}{c}81 \pm \\
3.7 \\
9\end{array}$ & $\begin{array}{c}14.64 \\
\pm \\
0.72\end{array}$ & $\begin{array}{c}96.83 \\
\pm \\
4.76\end{array}$ & $\begin{array}{c}16.56 \\
\pm \\
0.48\end{array}$ & $\begin{array}{c}98.57 \\
\pm \\
1.43\end{array}$ & $\begin{array}{c}17.76 \\
\pm \\
0.24\end{array}$ & $\begin{array}{c}98.67 \\
\pm \\
1.33\end{array}$ & $\begin{array}{c}19.20 \\
\pm \\
0.24\end{array}$ & $\begin{array}{c}100.0 \\
0 \pm \\
1.25\end{array}$ & $\begin{array}{c}20.40 \\
\pm \\
0.24\end{array}$ & $\begin{array}{c}100.0 \\
0 \pm \\
1.18\end{array}$ & - & - & $\begin{array}{c}19.20 \\
\pm \\
0.24\end{array}$ & $\begin{array}{c}100.0 \\
0 \pm \\
1.25\end{array}$ \\
\hline $\mathbf{P}_{3}$ & $\begin{array}{c}93 \pm \\
1.9 \\
b\end{array}$ & $\begin{array}{c}13.92 \\
\pm \\
0.24 \\
\mathrm{a}\end{array}$ & $\begin{array}{c}92.06 \\
\pm \\
1.59 \\
\mathrm{a}\end{array}$ & $\begin{array}{c}15.84 \\
\pm \\
0.24 \\
\mathrm{a}\end{array}$ & $\begin{array}{c}94.28 \\
\pm \\
1.43 \\
\mathrm{a}\end{array}$ & $\begin{array}{c}17.04 \\
\pm \\
0.24 \\
\mathrm{a}\end{array}$ & $\begin{array}{c}94.66 \\
\pm \\
1.33 \\
\mathrm{a}\end{array}$ & $\begin{array}{c}18.48 \\
\pm \\
0.24\end{array}$ & $\begin{array}{c}96.25 \\
\pm \\
1.25\end{array}$ & $\begin{array}{c}19.92 \\
\pm \\
0.48\end{array}$ & $\begin{array}{c}97.64 \\
\pm \\
2.35\end{array}$ & $\begin{array}{c}22.32 \\
\pm \\
5.28\end{array}$ & & $\begin{array}{c}18.48 \\
\pm \\
0.24 \\
\mathrm{~b}\end{array}$ & $\begin{array}{c}96.25 \\
\pm \\
1.25 \\
\mathrm{~b}\end{array}$ \\
\hline
\end{tabular}


ISSN: 2456-1878

\begin{tabular}{|c|c|c|c|c|c|c|c|c|c|c|c|c|c|c|c|}
\hline & & 13.68 & 90.48 & 15.60 & 92.86 & 16.80 & 93.33 & 18.00 & 93.75 & 19.44 & 95.29 & 20.88 & & 18.24 & 95.00 \\
$\mathbf{P}_{4}$ & 1 & \pm & \pm & \pm & \pm & \pm & \pm & \pm & \pm & \pm & \pm & \pm & & \pm & \pm \\
& $\mathrm{c}$ & 0.48 & 3.17 & 0.24 & 1.43 & 0.24 & 1.33 & 0.24 & 1.25 & 0.24 & 1.18 & 0.24 & - & 0.24 & 1.25 \\
& & $\mathrm{a}$ & $\mathrm{a}$ & $\mathrm{a}$ & $\mathrm{a}$ & $\mathrm{b}$ & $\mathrm{b}$ & $\mathrm{b}$ & $\mathrm{b}$ & $\mathrm{b}$ & $\mathrm{b}$ & & & $\mathrm{b}$ & $\mathrm{b}$ \\
\hline & & 13.44 & 88.89 & 15.36 & 91.43 & 16.56 & 92.00 & 18.00 & 93.75 & 19.20 & 94.12 & 20.64 & & 18.00 & 93.75 \\
$\mathbf{P}_{5}$ & $96 \pm$ & \pm & \pm & \pm & \pm & \pm & \pm & \pm & \pm & \pm & \pm & \pm & - & \pm & \pm \\
& 1 & 0.24 & 1.59 & 0.24 & 1.43 & 0.24 & 1.33 & 0.24 & 1.25 & 0.24 & 1.18 & 0.24 & 0.24 & 1.25 \\
& $\mathrm{c}$ & $\mathrm{a}$ & $\mathrm{a}$ & $\mathrm{b}$ & $\mathrm{b}$ & $\mathrm{b}$ & $\mathrm{b}$ & $\mathrm{c}$ & $\mathrm{c}$ & $\mathrm{b}$ & $\mathrm{b}$ & & & $\mathrm{c}$ & $\mathrm{c}$ \\
\hline
\end{tabular}

Table.3:Germination parameters determined for triticale seeds exposed to $250 \mathrm{mT}$ stationary magnetic fields, expressed as mean value and standard error and as percentage. $G_{\text {max }}$ : number of germinated seeds (\%); MGT: Mean germination time;

$T_{1}, T_{10}, T_{25}, T_{50}, T_{75}, T_{90}$ : time needed to obtain 1, 10, 25, 50, 75 and $90 \%$ of seeds to germinate, expressed in hours. Asterisks indicate differences vs. control: *** $(p<0.001) ; * *(0.001<p<0.01) ; *(0.01<p<0.05)$. Doses $250 \mathrm{mT}$ : P6 (1 min), P7 (10 min), P8 (20 min), P9 (1hour) P10 (24 hours); C (Control).

\begin{tabular}{|c|c|c|c|c|c|c|c|c|c|c|c|c|c|c|c|}
\hline \multirow{2}{*}{$\begin{array}{c} \\
\mathbf{2 5} \\
\mathbf{0} \\
\mathbf{m} \\
\mathbf{T}\end{array}$} & \multirow{2}{*}{$\begin{array}{c}\mathbf{G}_{\mathrm{ma}} \\
\mathbf{x}\end{array}$} & \multicolumn{2}{|c|}{$\mathbf{T}_{1}$} & \multicolumn{2}{|c|}{$T_{10}$} & \multicolumn{2}{|c|}{$\mathbf{T}_{25}$} & \multicolumn{2}{|c|}{$\mathbf{T}_{50}$} & \multicolumn{2}{|c|}{$\mathbf{T}_{75}$} & \multicolumn{2}{|c|}{$T_{90}$} & \multicolumn{2}{|c|}{ MGT } \\
\hline & & $\begin{array}{c}\text { hour } \\
\mathbf{s}\end{array}$ & $\%$ & $\begin{array}{c}\text { hour } \\
\mathbf{s}\end{array}$ & $\%$ & $\begin{array}{c}\text { hour } \\
\text { s }\end{array}$ & $\%$ & $\begin{array}{c}\text { hour } \\
\mathbf{s}\end{array}$ & $\%$ & $\begin{array}{c}\text { hour } \\
\mathbf{s}\end{array}$ & $\%$ & $\begin{array}{c}\text { hour } \\
\text { s }\end{array}$ & $\%$ & $\begin{array}{c}\text { hour } \\
\mathbf{s}\end{array}$ & $\%$ \\
\hline C & $\begin{array}{c}80 \pm \\
1.6 \\
3\end{array}$ & $\begin{array}{c}15.12 \\
\pm \\
0.24\end{array}$ & 100 & $\begin{array}{c}16.80 \\
\pm \\
0.24\end{array}$ & 100 & $\begin{array}{c}18.00 \\
\pm \\
0.24\end{array}$ & 100 & $\begin{array}{c}19.20 \\
\pm \\
0.24\end{array}$ & 100 & $\begin{array}{c}20.40 \\
\pm \\
0.24\end{array}$ & 100 & - & - & $\begin{array}{c}19.20 \\
\pm \\
0.24\end{array}$ & 100 \\
\hline $\mathbf{P}_{6}$ & $\begin{array}{c}88 \pm \\
2.8 \\
3\end{array}$ & $\begin{array}{c}14.40 \\
\pm \\
0.48\end{array}$ & $\begin{array}{c}95.24 \\
\pm \\
3.17\end{array}$ & $\begin{array}{c}16.32 \\
\pm \\
0.24\end{array}$ & $\begin{array}{c}97.14 \\
\pm \\
1.43\end{array}$ & $\begin{array}{c}17.52 \\
\pm \\
0.24\end{array}$ & $\begin{array}{c}97.33 \\
\pm \\
1.33\end{array}$ & $\begin{array}{c}18.72 \\
\pm \\
0.24\end{array}$ & $\begin{array}{c}97.50 \\
\pm \\
1.25\end{array}$ & $\begin{array}{c}20.16 \\
\pm \\
0.24\end{array}$ & $\begin{array}{c}98.82 \\
\pm \\
1.18\end{array}$ & - & - & $\begin{array}{c}18.96 \\
\pm \\
0.24\end{array}$ & $\begin{array}{c}98.75 \\
\pm \\
1.11\end{array}$ \\
\hline $\mathbf{P}_{7}$ & $\begin{array}{c}89 \pm \\
2.5 \\
\mathrm{a}\end{array}$ & $\begin{array}{c}14.16 \\
\pm \\
0.24\end{array}$ & $\begin{array}{c}93.65 \\
\pm \\
1.59\end{array}$ & $\begin{array}{c}16.08 \\
\pm \\
0.24\end{array}$ & $\begin{array}{c}95.71 \\
\pm \\
1.43\end{array}$ & $\begin{array}{c}17.28 \\
\pm \\
0.24\end{array}$ & $\begin{array}{c}96.00 \\
\pm \\
1.33\end{array}$ & $\begin{array}{c}18.72 \\
\pm \\
0.00\end{array}$ & $\begin{array}{c}97.50 \\
\pm \\
0.00\end{array}$ & $\begin{array}{c}20.16 \\
\pm \\
0.00\end{array}$ & $\begin{array}{c}98.82 \\
\pm \\
0.00\end{array}$ & $\begin{array}{c}21.6 \pm \\
0.24\end{array}$ & - & $\begin{array}{c}18.72 \\
\pm \\
0.24\end{array}$ & $\begin{array}{c}97.5 \pm \\
1.25\end{array}$ \\
\hline $\mathbf{P}_{8}$ & $\begin{array}{c}94 \pm \\
1.1 \\
5 \\
\mathrm{c}\end{array}$ & $\begin{array}{c}13.44 \\
\pm \\
0.24 \\
\mathrm{~b}\end{array}$ & $\begin{array}{c}88.89 \\
\pm \\
1.59 \\
\mathrm{~b}\end{array}$ & $\begin{array}{c}15.60 \\
\pm \\
0.24 \\
\mathrm{~b}\end{array}$ & $\begin{array}{c}92.86 \\
\pm \\
1.43 \\
\mathrm{~b}\end{array}$ & $\begin{array}{c}16.80 \\
\pm \\
0.24 \\
\mathrm{~b}\end{array}$ & $\begin{array}{c}93.33 \\
\pm \\
1.33 \\
\mathrm{~b}\end{array}$ & $\begin{array}{c}18.24 \\
\pm \\
0.24 \\
\mathrm{a}\end{array}$ & $\begin{array}{c}95.00 \\
\pm \\
1.25 \\
\mathrm{a}\end{array}$ & $\begin{array}{c}19.92 \\
\pm \\
0.24\end{array}$ & $\begin{array}{c}97.65 \\
\pm \\
1.18\end{array}$ & $\begin{array}{c}20.88 \\
\pm \\
0.24\end{array}$ & & $\begin{array}{c}18.48 \\
\pm \\
0.24 \\
\mathrm{a}\end{array}$ & $\begin{array}{c}96.25 \\
\pm \\
1.11 \\
\mathrm{a}\end{array}$ \\
\hline $\mathbf{P}_{9}$ & $\begin{array}{c}95 \pm \\
3.7 \\
9 \\
a\end{array}$ & $\begin{array}{c}13.20 \\
\pm \\
0.24 \\
\mathrm{~b}\end{array}$ & $\begin{array}{c}87.30 \\
\pm \\
1.59 \\
\mathrm{~b}\end{array}$ & $\begin{array}{c}15.36 \\
\pm \\
0.24 \\
\mathrm{~b}\end{array}$ & $\begin{array}{c}91.43 \\
\pm \\
1.43 \\
\mathrm{~b}\end{array}$ & $\begin{array}{c}16.56 \\
\pm \\
0.24 \\
\mathrm{~b}\end{array}$ & $\begin{array}{c}92.00 \\
\pm \\
1.33 \\
\mathrm{~b}\end{array}$ & $\begin{array}{c}18.00 \\
\pm \\
0.24 \\
\mathrm{~b}\end{array}$ & $\begin{array}{c}93.75 \\
\pm \\
1.25 \\
\mathrm{~b}\end{array}$ & $\begin{array}{c}19.68 \\
\pm \\
0.24 \\
\mathrm{a}\end{array}$ & $\begin{array}{c}96.47 \\
\pm \\
1.18 \\
\mathrm{a}\end{array}$ & $\begin{array}{c}20.88 \\
\pm \\
0.24\end{array}$ & - & $\begin{array}{c}18.24 \\
\pm \\
0.24 \\
\mathrm{~b}\end{array}$ & $\begin{array}{c}95.00 \\
\pm \\
1.11 \\
\mathrm{~b}\end{array}$ \\
\hline $\begin{array}{c}\mathbf{P}_{1} \\
0\end{array}$ & $\begin{array}{c}99 \pm \\
1 \\
\text { c }\end{array}$ & $\begin{array}{c}12.72 \\
\pm \\
0.24 \\
\mathrm{~b}\end{array}$ & $\begin{array}{c}84.13 \\
\pm \\
1.59 \\
\mathrm{~b}\end{array}$ & $\begin{array}{c}14.88 \\
\pm \\
0.24 \\
\mathrm{c}\end{array}$ & $\begin{array}{c}88.57 \\
\pm \\
1.43 \\
\mathrm{c}\end{array}$ & $\begin{array}{c}16.32 \\
\pm \\
0.24 \\
\mathrm{c}\end{array}$ & $\begin{array}{c}90.67 \\
\pm \\
1.33 \\
\mathrm{c}\end{array}$ & $\begin{array}{c}17.76 \\
\pm \\
0.24 \\
\mathrm{c}\end{array}$ & $\begin{array}{c}92.50 \\
\pm \\
1.25 \\
\mathrm{c}\end{array}$ & $\begin{array}{c}19.44 \\
\pm \\
0.24 \\
\text { b }\end{array}$ & $\begin{array}{c}95.29 \\
\pm \\
1.18 \\
\mathrm{~b}\end{array}$ & $\begin{array}{c}20.64 \\
\pm \\
0.24\end{array}$ & & $\begin{array}{c}18.00 \\
\pm \\
0.24 \\
\mathrm{c}\end{array}$ & $\begin{array}{c}93.75 \\
\pm \\
1.11 \\
\mathrm{c}\end{array}$ \\
\hline
\end{tabular}

Soltani, Kashi and Arghavani (2006 a, b) found the effect of a magnetic field on Asparagus officinalis and Ocimum basilicum seed germination and seedling growth to be positive. Souza et al. (2006) found that the leaf, stem and root relative growth rates of tomato plants grown from magnetically treated seeds were greater than those of control plants. Vashisth and Nagarajan (2008) observed that magnetic field application enhanced chickpea seed germination speed, seedling length and seedling dry weight. Seeds were exposed in batches to static magnetic fields ranging in intervals of $50 \mathrm{mT}$ of from 0 to $250 \mathrm{mT}$ for 1-4 h in steps of 1 hour for all fields. Best results were obtained from exposures of $50 \mathrm{mT}$ for $2 \mathrm{~h}, 100 \mathrm{mT}$ for $1 \mathrm{~h}$ and $150 \mathrm{mT}$ for $2 \mathrm{~h}$. Pietruszewski and Kania (2010) observed accelerated germination after magnetic stimulation of wheat seeds. They worked with 30, 45 and $60 \mathrm{mT}$ magnetic field strengths. 
In previous studies authors found an increase in the rate of germination of seeds and a stimulation of growth of seedlings. They found a positive growth response to a 125 $\mathrm{mT}$ and $250 \mathrm{mT}$ magnetic field in rice, wheat and barley seeds (Florez 2004; Martinez et al. 2000, 2002). The greatest stimulation of growth was observed in seeds chronically exposed to a magnetic field or in seeds treated for 24 hours. An increase of the initial growth stages and an early sprouting of maize seeds exposed to a stationary magnetic field was also observed by Flórez, Carbonell and Martínez (2007), whose treated plants grew higher and heavier than control. Carbonell et al. (2008) studied the effect of exposure of grass seeds to $125 \mathrm{mT}$ and 250 $\mathrm{mT}$, finding that mean germination time was reduced by $10 \%$ compared with control seeds; the time required for germination onset was also reduced and the roots of grass seedlings from chronically exposed seeds grew higher and longer than those of untreated ones. Recently they have also obtained an early germination in Salvia officinalis L. and Calendula officinalis L. (Florez et al, 2012).
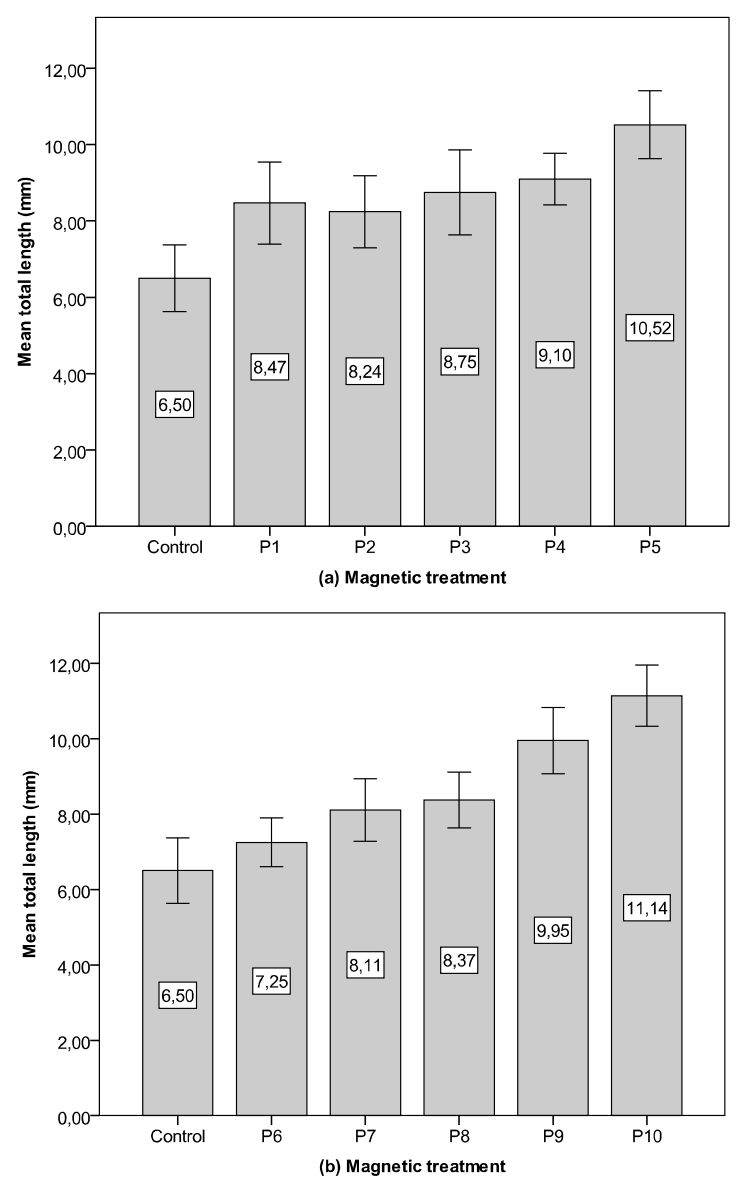

Fig.1:Mean total length of triticale plants from seeds exposed to 125 and $250 m T$, measured on $2^{\text {nd }}$ day, including the $95 \%$ confidence intervals. (a) Mean total length for doses $125 \mathrm{mT}$ : P1 (1 min), P2 (10 min), P3 (20 min), P4 (1hour), P5 (24 hours); C (Control). (b) Mean total length for doses $250 \mathrm{mT}$ : P6 (1 min), P7 (10 min), P8 (20 min), P9 (1hour), P10 (24 hours); C (Control).
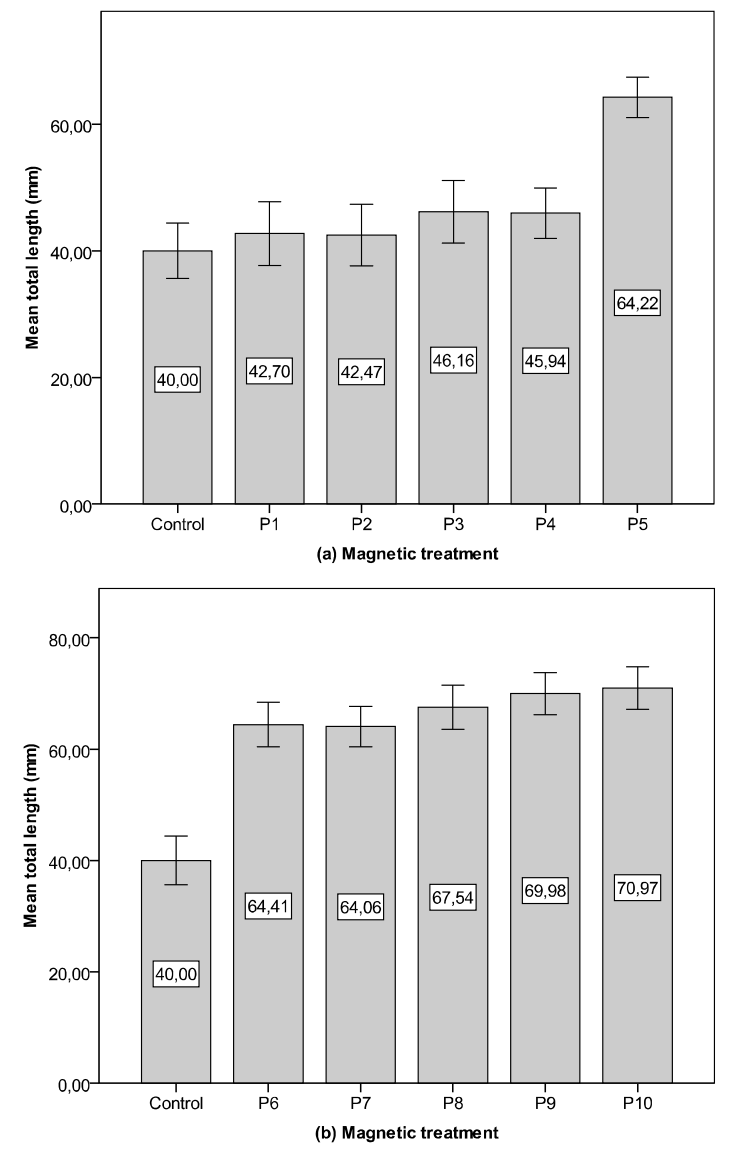

Fig.2: Mean total length of triticale plants from seeds exposed to 125 and $250 \mathrm{mT}$, measured on $4^{\text {th }}$ day, including the $95 \%$ confidence intervals. (a) Mean total length for doses $125 \mathrm{mT}$ : P1 (1 min), P2 (10 min), P3 (20 min), P4 (1hour), P5 (24 hours); C (Control). (b) Mean total length for doses $250 \mathrm{mT}$ : P6 (1 min), P7 (10 min), P8 (20min), P9 (1hour), P10 (24 hours); C (Control).

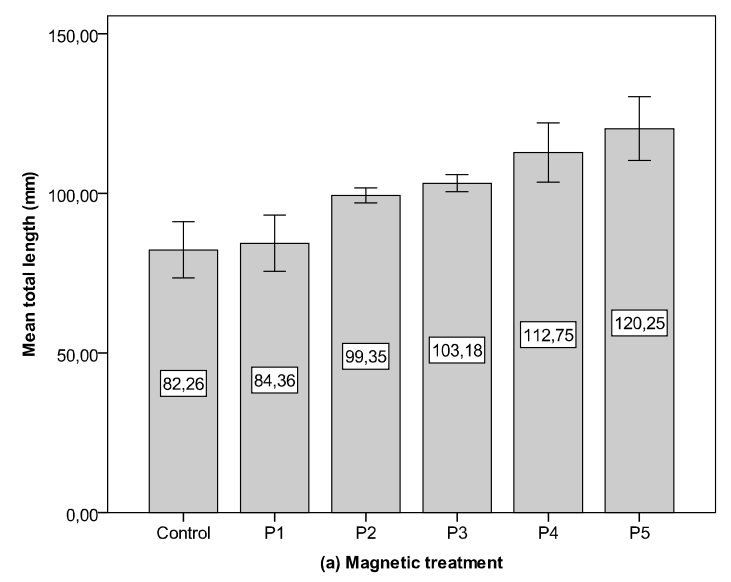




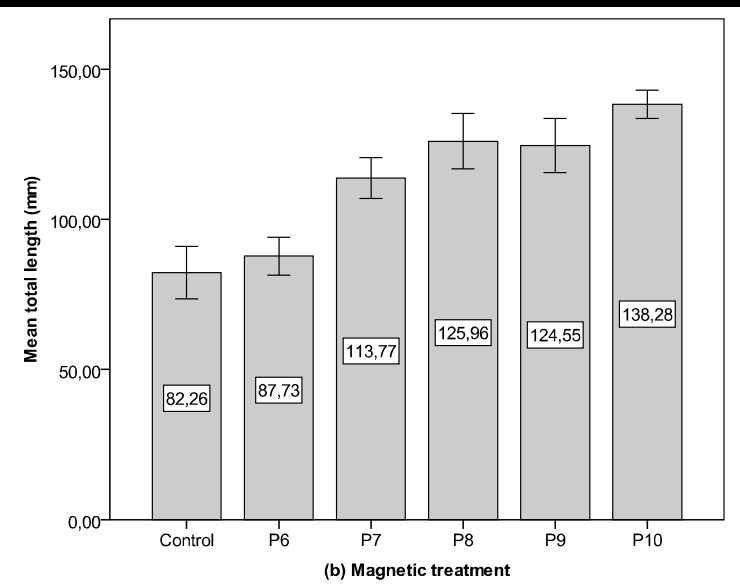

Fig.3:Mean total length of triticale plants from seeds exposed to 125 and $250 \mathrm{mT}$, measured on $6^{\text {th }}$ day, including the $95 \%$ confidence intervals. (a) Mean total length for doses $125 \mathrm{mT}$ : P1 (1 min), P2 (10 min), P3 (20 min), P4 (1hour), P5 (24 hours); C (Control). (b) Mean total length for doses $250 \mathrm{mT}$ : P6 (1 min), P7 (10 min), P8 (20 min), P9 (1hour), P10 (24 hours); C (Control).

\section{CONCLUSION}

Results obtained in this study allow us to conclude that magnetic treatment improves germination rate of triticale seeds. In general, most of the parameters recorded for all the doses applied to triticale seeds were better than control values. Thus, the rate of germination of treated triticale seeds was higher than the untreated seed (C) rate. The greatest reductions in the mean germination time (the most important parameter) were for P10 (24h to $250 \mathrm{mT}$ ) and P5 (24h to $125 \mathrm{mT}$ ) doses.

Furthermore, seedlings from magnetically treated seeds grew taller than control. Seedlings from P10 and P5 obtained the longest mean total length during the 3 days of measurement (days 2, 4 and 6 after sowing).

\section{ACKNOWLEDGEMENTS}

The Technical University of Madrid (UPM) has supported this research, carried out by members of the research group "Investigation in Bioelectromagnetism Applied to Agroforestry Engineer", through the Project N.CCG07-UPM/0003348.

\section{REFERENCES}

[1] A. Aladjadjiyan. 2002. Study of the influence of magnetic field on some biological characteristics of Zea mais. J. Cent. Eur. Agric. 2(3): 89-94, 2002.

[2] T. Cakmak, R. Dumlupinar, S. Erdal. 2010. Acceleration of germination and early growth of wheat and bean seedlings grown under various magnetic field and osmotic conditions. Bioelectromagn. 2(31):120-129.
[3] M.V. Carbonell, E. Martínez, M. Flórez, R: Maqueda, A. López-Pintor and J.M. Amaya. 2008. Magnetic field treatments improve germination and seedling growth in Festuca arundinacea Schreb. and Lolium perenne L. Seed Sci. Tech. 36: 31-37.

[4] M.V. Carbonell, M. Flórez, E. Martínez, R. Maqueda, and J.M. Amaya. 2011. Study of stationary magnetic fields on initial growth of pea (Pisum sativum L.) Seed Sci. Tech. 39:673-679.

[5] M. Flórez. 2004. Efecto de campos magnéticos estacionarios de $125 \mathrm{mT}$ y $250 \mathrm{mT}$ en la germinación de semillas y desarrollo de plántulas (in Spanish). Tesis doctoral. Escuela Técnica Superior de Ingenieros Agrónomos, Universidad Politécnica de Madrid.

[6] M. Flórez, M.V. Carbonell, E. Martínez. 2007. Exposure of maize seeds to stationary magnetic fields: effects on germination and early growth. Environ. Exp. Bot. 1(59):68-75.

[7] M. Flórez, E. Martínez, M.V. Carbonell, 2012. Effect of magnetic field treatment on germination of medicinal plants Salvia officinalis L. and Calendula officinalis L. Polish J.Environ. Stu. 1(21): 57-63.

[8] F. García, L.I: Arza. 2001. Influence of a stationary magnetic field on water relations in lettuce seeds. Part I: Theoretical considerations. Bioelectromag. 8(22):589-595.

[9] ISTA. 2004 International Seed Testing Association. International Rules for Seed Testing. Seed Sci. Tech.

[10]E. Martínez, M.V. Carbonell, J.M. Amaya. 2000. Static magnetic field of $125 \mathrm{mT}$ stimulates the initial growth stages of barley (Hordeum vulgare 1.). Electromag. 3(1):271-277.

[11]E. Martínez, M.V. Carbonell, M.Florez. 2002. Magnetic biostimulation of initial growth stages of wheat (Triticum aestivum, L.). Elect. Biol. and Medic.1(21):43-53..

[12]P.S. Phirke, A.B. Kubde, S.P. Umbakar. 1996. The influence of magnetic field on plant growth. Seed Sci. Tech.24:375-392.

[13] S. Pietruszewski, K. Kania. 2010. Effect of magnetic field on germination and yield of wheat. Int. Agroph. 24:297-302.

[14]PODLESNI, J.; PIETRUSZEWSKI, S.; PODLESNA, A. Efficiency of the magnetic treatment of broad bean seeds cultivated under experimental plot conditions. International Agrophysics, Lublin (Poland), v. 1, n. 18, p. 65-71, 2004.

[15] SHINE, M.B.; GURUPRASAD, K.N.; ANAND, A. Enhancement of germination, growth and photosynthesis in soybean by pre-treatment of seeds 
with magnetic field. Bioelectromagnetics, Malden (USA), v. 6, n. 32, p. 474-484, 2011.

[16]F. Soltani, A. Kashi, M. Arghavani. 2006a. Effect of magnetic field on asparagus officinalis 1. seed germination and seedling growth. Seed Scie. Tech. 5(34): 349-353

[17]F. Soltani, A. Kashi, M. Arghavani. 2006b. Effect of magnetic field on ocimum basilicum seed germination and seedling growth. Acta Hortic. 723:. 279-282.

[18] A. Souza, D. García, L. Sueiro, F. Gilart, E. Porras and L. Licea.2006. Pre-sowing magnetic treatments of tomato seeds increase the growth and yield of plants. Bioelectromag. 4(27):247-257.

[19] A. Vashisth, A., N. Nagarajan. 2008. Exposure of seeds to static magnetic field enhances germination and early growth characteristics in chickpea. Bioelectrom.7(29): 571-578.

[20] A. Yano, E. Hidaka, E, K. Fujiwara and M. Iimot. 2001 Induction of primary root curvature in radish seedlings in a static magnetic field. Bioelectromag.22:194-199 